\title{
Modul \\ Edukasi Keuangan Koperasi
}

\author{
Penulis:
}

Nihlatul Qudus Sukma Nirwana

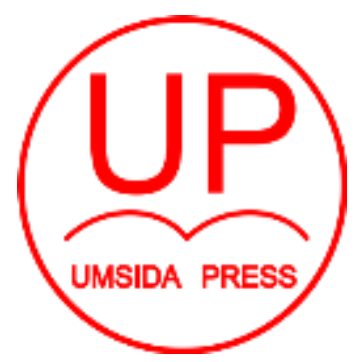

Diterbitkan oleh

\section{UMSIDA PRESS}

Jl. Mojopahit 666 B Sidoarjo

ISBN: 978-623-6081-29-7

Copyright@2021.

Authors

All rights reserved 


\section{Modul}

Edukasi Keuangan Koperasi

\section{Penulis :}

Nihlatul Qudus Sukma Nirwana

\section{ISBN :}

978-623-6081-29-7

\section{Editor :}

M.Tanzil Multazam,S.H,.M.Kn

Mahardika Darmawan K.W.,M.Pd

\section{Copy Editor :}

Wiwit Wahyu Wijayanti

\section{Design Sampul dan Tata Letak :}

\section{Penerbit :}

UMSIDA Press

\section{Redaksi :}

Universitas Muhammadiyah Sidoarjo

Jl. Mojopahit No 666B

Sidoarjo, Jawa TImur

Cetakan pertama, Maret 2021

(C) Hak cipta dilindungi undang-undang

Dilarang memperbanyak karya tulis ini dengan suatu apapun tanpa ijin tertulis dari penerbit. 


\section{KATA PENGANTAR}

Bismillaahirrahmaanirrahim.

Alhamdulillah, Puji syukur kita panjatkan kehadiran Allah SWT atas segala limpahan rahmatNya, sehingga kami dari Tim Abdimas UMSIDA dapat menyusun modul Keuangan Koperasi ini sebagai panduan dalam menjalankan pengelolaan koperasi BUEKA Penatarsewu Tanggulangin.

Modul ini berisikan tentang bagaimana pengurus dalam melakukan pengelolaan keuangan sesuai dengan prinsip akuntasi, membuat laporan keuangan mulai dari penjurnalan dari transaksi, pemostingan dalam Buku besar dan Buku Besar pembantu, pembuatan laporan laba rugi (PHU), Laporan perubahan modal, Neraca.seta bagaimana melakukan perhitungan SHU Anggota.

Tentu masih banyak terdapat kekurangan dalam modul ini sebagai panduan dan pengetahuan. Untuk itu kritik dan saran yang konstruktif sangat kami harapkan demi pengembangan dan kemajuan koperasi. 
Kami menyampaikan terimakasih yang sebesarbesarnya kepada Pengurus dan Pengawas Koperasi BUEKA serta berbagai pihak yang mendukung atas terselesainya modul ini.

Semoga modul ini bermanfaat bagi yang membaca pada umumnya dan bagi koperasi BUEKA pada khususnya sehingga dapat mempermudah Langkah kita dalam mengembangkan koperasi. Aamiin.

Sidoarjo 06 Maret 2021

Tim ABDIMAS . 


\section{DAFTAR ISI}

Kata Pengantar........................................... i

Daftar Isi.............................................. ii

\section{BAB I KOPERASI SEBAGAI LEMBAGA EKONOMI}

1.1 Pendahuluan ............................................ 1

1.2 Faktor-fakdor yang Mendukung Kemampuan Usaha Koperasi ............................................ 4

1.3 Kelebihan dalam berkoperasi .......................... 4

1.4 Kelemahan dan Hambatan Kegiatan Usaha Koperasi dan Upaya Pemecahannya ................................ 5

\section{BAB II PENGENDALIAN INTERNAL}

2.1 Pengendalian Intern ................................... 9

2.2 Pengendalian Administrasi dan Pengendalian Akuntansi.10

2.3 Prinsip-prinsip Pengendalian Intern ................... 11

2.4 Kelemahan Pengendalian Intern ...................... 12

2.5 Sistem Pengendalian Intern yang Baik ................. 15

\section{BAB III SISTEM PENGENDALIAN INTERN YANG BAIK}

3.1 Pernyataan Standar Akuntansi Keuangan No.27 (Revisi 1998) ................................................ 18

\section{BAB IV PERSAMAAN DAN SIKLUS AKUNTANSI}

4.1 Pengertian Akuntansi ................................... 21

4.2 Akuntansi Sebagai Suatu Sistem Informasi ............. 22

4.3 Akuntansi Sebagai Suatu Teknik Prosedur Pembukuan Transaksi Keuangan Koperasi .......................... 23

4.4 Fungsi Akuntansi .................................... 24

4.5 Persamaan Akuntansi ................................. 25 


\section{BAB V PERMODALAN}

5.1 Modal Koperasi ...................................... 42

5.2 Perhitungan Hasil Usaha ........................... 43

BAB 6 APLIKASI AKUNTANSI DAN STANDART

LAPORAN KEUANGAN ......................... 47

DAFTAR PUSTAKA 


\section{BAB 1 Koperasi sebagai Lembaga Ekonomi}

\subsection{PENDAHULUAN}

Menurut Undang-Undang No.25 Tahun 1992, koperasi merupakan suatu badan usaha yang berbadan hukum dengan anggota yang terdiri dari orang perorang sesuai dengan prinsip koperasi yang berasaskan kekeluargaan. Selain itu koperasi juga dapat melakukan adalah :

a. Peningkatan kesejahteraan masyarakat dengan cara melakukan pengembangan potensi dan pembangunan an masyarakat terutama anggotanya.

b. Secara aktif meningkatkan kualitas ekonomi masyarakat.

c. Memperkokoh perekonomian rakyat sebagai dasar kekuatan dan ketahanan perekonomian nasional dengan koperasi sebagai soko gurunya

d. Mewujudkan perekonomian nasional yang Tangguh berdasar atas asas kekeluargaan

Selain pemerintah dan swasta, koperasi juga berperan serta dalam memberikan kontribunya terhadap pendapatan negara meskipun jauh lebih kecil dibandingkan dengan 
yang lainnya. Namun itu tidak menyurutkan semangat pengurus dalam mengelola sehingga meskipun terjadi krisis, koperasi masih tetap berdiri kokoh hingga sampai sekarang. Kelebihan ini membuat koperasi menjadi patut untuk dilihat.

Koperasi diharapkan dapat tumbuh menjadi lembaga ekonomi yang kuat dan menjadi wadah utama untuk pembinaan kemampuan usaha golongan ekonomi lemah. Selain itu juga sebagai Pusat Pelayanan, koperasi juga harus dapat menghasilkan dan berguna untuk kepentingan masyarakat daerah tersebut. Misalkan dalam berbagai sector industry, pertanian, jasa, serta kegiatan yang lainnya.

Berdasarkan tingkatan koperasi dibagi menjadi 2 jenis yaitu :

1. Koperasi Primer yaitu koperasi yang beranggotakan orang-orang

2. Koperasi Sekunder.yaitu koperasi yang beranggotakan beberapa koperasi

Sedangkan berdasarkan jenisnya koperasi dibagi menjadi 4 yaitu : 
1. Koperasi Produksi (koperasi yang melakukan usaha produksi atau menghasilkan barang dimana koperasi ini beranggotakan para UKM)

2. Koperasi Konsumsi (Koperasi yang menyediakan semua kebutuhan para anggota dalam bentuk barang)

3. Koperasi Simpan Pinjam (koperasi yang melayani anggotanya untuk menabung dengan mendapatkan imbalan serta melayani pembiayaan/kredit dengan pengembalian yang ringan)

4. Koperasi serba Usaha (koperasi yang memiliki beberapa jenis usaha)

Bidang-bidang kegiatan pelayanan Koperasi terdiri dari :.

1. Usaha simpan pinjam.

2. Penyediaan dan penyaluran bahan kebutuhan pokok dan jasa jasa lainnya.

3. Pengolahan dan pemasaran hasil- hasil produksi.

4. Kegiatan perekonomian yang dibutuhkan oleh anggota.

Pendidikan dan pelatihan sangat penting dilakukan guna

Peningkatan skill koperasi dalam menjalankan usahanya. 


\subsection{Faktor-fakdor yang Mendukung Kemampuan Usaha Koperasi}

Faktor - faktor upaya pengembangan koperasi terdiri atas unsur-unsur :

1. SDM sebagai pelaksana "KEWIRAUSAHAAN",

2. Memiliki tempat dan prasarana yang memadai.

3. Memiliki modal baik dari simpanan anggota maupun dari luar anggota;

4. Melaksanakan system manajemen dengan baik.

5. Kemampuan koperasi dalam berinteraksi terhadap kebijakan dengan pihak luar...

\subsection{Kelebihan dalam berkoperasi}

Kelebihan koperasi sebagai sebuah badan usaha adalah sebagai berikut :

1. Koperasi mengutamakan kepentingan para anggotanya..

2. Anggota berperan sebagai pemilik sekaligus pengguna. Dengan cara aktif melakukan simpan pinjam..

3. Bebas dan terbuka, tanpa paksaan dari pihak manapun.

4. Keuntungan koperasi digunakan untuk kesejahteraan anggotanya. 
5. Sesuai dengan sifat bangsa Indonesia yang menjunjung tinggi nilai kekeluargaan serta kegotong-royongan.

6. Rata-rata anggota koperasi berpenghasilan menengah ke bawah.

7. Memiliki hak berpendapat yang sama.

8. Koperasi memudahkan anggotanya untuk mendapatkan modal usaha.

9. Besaran Modal sendiri sesuai keputusan hasil RAT.

10. Peningkatan kesejahteraan anggota lebih diutamakan dibandingkan dengan keuntungan pribadi.

\subsection{Hambatan Kegiatan Usaha Koperasi dan Upaya}

\section{Pemecahannya}

Secara konseptual dan operasional Usaha koperasi masih banyak memiliki kelemahan.

Kelemahan koperasi sebagai berikut:

1. Kurang adanya kesadaran dalam berkoperasi.

Contoh, anggota tidak rutin menyetorkan iuran wajib.

2. Memiliki daya saing yang lemah. Umum diketahui bahwa jika dibandingkan dengan badan 
usaha lainnya, daya saing koperasi masih jauh tertinggal.

3. Keterbatasan modal koperasi dan kendala dalam mendapatkannya..

4. Pengelolaan koperasi tidak didukung oleh tenaga profesional. Salah satu faktor rendahnya pengelolaan koperasi dikarenakan kurang adanya SDM yang kompeten dalam mengurus dan mengelola koperasi sehingga koordinasi antara pengurus, pengelola, pengawas, dan anggota tidak berjalan dengan baik.

\section{Terdapat konflik kepentingan di koperasi.}

Disamping hambatan tersebut di atas, koperasi masih menghadapi masalah eksternal, antara lain sikap hidup masyarakat,taraf pendidikan masyarakat, kebijaksanaan dan peraturan pemerintah, kondisi perekonomian, sistem perbankan yang berlaku, dan sebagainya yang berpengaruh kepada perkembangan usaha koperasi, Menghadapi kelemahan/hambatan di bidang usaha koperasi, maka untuk mempercepat proses keberhasilan suatu koperasi perlu ditempuh upaya-upaya pemecahan, antara lain sebagai berikut. 
1. Mengidentifkasikan potensi ekonomi, business plan, dan menyusun organisasi serta menyiapkan karyawan yang mempunyai keahlian di bidang usaha tersebut.

2. Mengikutsertakan pengurus dalam kegiatan Pendidikan dan pelatihan.

3. Pemantapan dan Pengembangan usaha koperasi melalui kegiatan program yang dirintis oleh pemerintah dan mempunyai keterkaitan langsung dengan kepentingan anggota maupun masyarakat, sehingga dengan keberhasilan penanganan kegiatan program tersebut akan mampu meningkatkan keterampilan, manajemen dan permodalan koperasi guna mendorong pengembangan kegiatan usaha swadaya (nonprogram) koperasi.

4. Pengembangan era digital merupakan pilihan yang tepat dalam meningkatkan keterampilan dalam mengelola sarana usaha koperasi.

5. Pelayanan terhadap anggota koperasi perlu ditingkatkan.

6. Meningkatkan volume usaha berdasarkan suatu perencanaan yang mantap melalui penekanan biaya sehingga produktif dan efisien. 
7. Pemberian bonus kepada pengurus sebagai motivasi perangsang keberhasilan kinerja dalam mencapai target minimal yang telah ditentukan. 


\section{BAB 2. PENGENDALIAN INTERN}

\subsection{Pengendalian Intern}

Di dalam manajemen, pandangan serta sikap profesional hendaknya dapat selalu dinyatakan dengan melihat, meneliti, menganalisis, dan mengambil keputusan atas laporan-laporan yang telah disampaikan, yang digunakan sebagai dasar dalam mengambil keputusan, baik untuk mengendalikan atau mengarahkan, biasanya berbentuk laporan akuntansi dan statistik.

Di samping berfungsi untuk mengendalikan dan mengarahkan, laporan juga mempunyai arti untuk menilai apakah kebijakan yang telah ditentukan dijalankan, apakah kondisi keuangan sehat, kegiatan penjualan menguntungkan, dan hubungan antar bagian atau unit usaha berlangsung harmonis. Pemeriksaan terus menerus dan analisis laporan dan catatan-catatan sering disebut Sistem Pengendalian Intern (SPI), Sistem Pengendalian Intern akan menghasilkan laporan yang dikehendaki manajemen, yaitu:

a. Mengamankan sumber-sumber dari pemborosan, kecurangan, dan ketidakefisienan 
b. Meningkatkan ketelitian dan dapat dipercayainya data akuntansi

c. Mendorong ditaati dan dilaksanakannya kebijakan badan usaha koperasi

d. Meningkatkan efsiensi.

\subsection{Pengendalian Administrasi dan Pengendalian}

\section{Akuntansi}

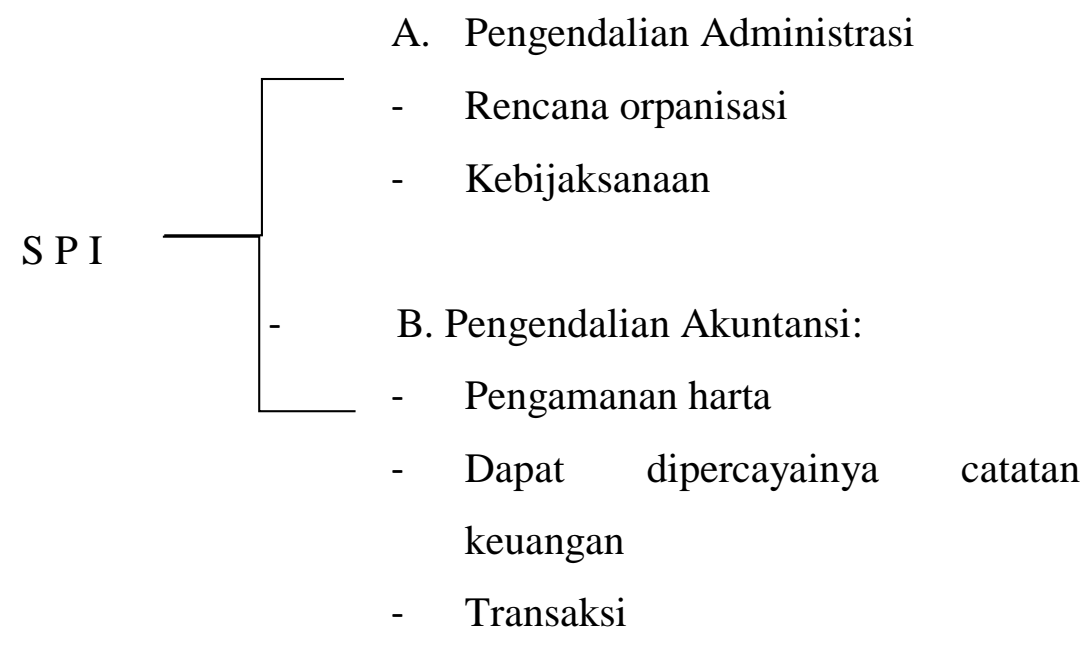

Gambar 2. Sistem Pengendalian Internal 


\subsection{Prinsip-prinsip Pengendalian Intern}

Prinsip-prinsip yang perlu diperhatikan agar didapatkan pengendalian/ pengawasan intern yang baik.

1. Pegawai / karyawan yang kapabel dan dapat dipercaya. Karyawan yang diberi tanggung jawab harus sesuai dengan kecakapan, pengalaman, dan kejujurannya.

2. Pemisahan wewenang. Dengan adanya Susunan Struktur organisasi menunjukkan adanya pemisahan tugas dan wewenang.

3. Pengawasan. Pengawasan terhadap kinerja karyawan sangat penting karena dapat menekan biaya jika terjadi penyelewengan yang dilakukan oleh karyawan.. Pimpinan bertanggung jawab terhadap karyawan untuk mengawasi mereka, agar mereka tetap jujur dan teguh imannya.

4. Penetapan tanggung jawab secara perorangan. Dengan adanya tanggung jawab secara perorangan dapat mempengaruhi psikologis sehingga mereka akan bekerja dengan baik dan waspada. 
5. Pemeriksaan otomatis berdasarkan prosedurprosedur rutin. Dibuat formulir sebagai alat pengendali.

6. Pencatatan yang saksama dan segera. Jika terjadi kesalahan dalam pencatatan dalam bukti transaksi maka harus segera ditandai dengan tanda "BATAL" dan diarsipkan dengan baik dan benar

7. Penjagaan fisik. Adanya lemari sebagai tempat arsip sehingga data tidak tercecer.

8. Pemeriksaan oleh petugas. Pengawas melakukan pemeriksaan secara continue

\subsection{Beberapa Kelemahan Pengendalian Intern Koperasi}

Ada beberapa kelemahan pengendalian intern di koperasi, yaitu sebagai berikut

1. Organisasi masih lemah

a) Belum adanya pembagian tugas secara tertulis. Hal ini menyebabkan kurang tertibnya pelaksanaan tugas dan pertanggungjawaban.

b) Masih adanya perangkapan tupns berbagai fungsi, yaitu fungsi pencatatan, fungsi 
pelaksnnaan, dan fungsi penyimpanan schingga menyulitkan pelaksanaan pengendalian intern,

c) Belum terwujudnya profesionalisme/tenaga terampil. Hal ini antara lain dapat dilihat dari adanya pemilihan, pengangkatan pengurus, pengawas, dan karyawan yang lebih mengedepankan pertimbangan:

- kawan terdekat;

- adanya rasa senang, tidak senang;

- adanya sistem keluarga.

2. Tidak ada/ kurang lengkapnya ketentuan-ketentuan yang mengatur tentang proses dan prosedur operasional.

a) Penetapan rencana kerja, Rencana Anggaran Pendapatan dan Belanja Koperasi baru berdasarkan formalitas, tidak dibahas secara mendalam dalam rapat khusus.

b) Sistem akuntansi sebagian masih lemah, meliputi: kelengkapan dan keabsahan data primer (bukti-bukti); pengerjaan sistem akuntansi yang terlambat dan keliru, 
c) Pengelolaan keuangan dan usaha masih banyak berdasarkan pada kebijaksanaan, dikarenakan ketentuan proses dan prosedurnya belum ada. Hal ini menimbulkan pelaksanaan yang kurang tertib, perasaan yang kurang puas.

3. Para pelaksana pengawasan belum melaksanakan tugas sebagaimana mestinya.

a) Pengawasan manajemen oleh Pengurus

Pengurus jarang melakukan pengawasan secara detail kepada manajer (keuangan, usaha, akuntansi). Bahkan terdapat di beberapa koperasi, peranan manajer terhadap pengurus sangat besar, sebab pengurus tidak menguasai bidangnya.

b) Pengawasan oleh Pengawas Koperasi

Banyak yang belum memiliki pengetahuan/keterampilan yang cukup memadai, dan ada yang kalah pengaruh dengan Pengurus, sehingga tidak berani mengadakan pemeriksaan secara lengkap.

4. Kurangnya penerapan sanksi. Jika terjadi kesalahan tidak dikenakan sanksi 


\subsection{Sistem Pengendalian Intern yang Baik}

\section{Dari Segi organisasi}

a. Struktur organisasi dilaksanakan sesuai dengan kebutuhan dan secara jelas memisahkan fungsifungsi pencatatan, pelaksanaan, dan pengawasan, serta lengkapnya job description yang tertulis dan jelas.

b. Dipergunakannya tenaga-tenaga yang cakap, terampil, dan jujur serta mau bekerja efektif-efisien, sehingga setiap pekerjaan dapat ditugaskan kepada personil yang mempunyai kecakapan yang sesuai dengan pekerjaan tersebut.

c. Menghindari adanya pemilihan/pengangkatan personil (pengurus, pengawas, karyawan) berdasarkan atas rasa senang dan tidak senang, kawan dekat, dan sistem keluarga.

\section{Segi pelaksanaan}

a. Rencana kerja, rencana anggaran pendapatan dan belanja merupakan tolok ukur keberhasilan kegiatan koperasi. RK dan RAPB ini dibahas dengan anggota, 
sehingga betul-betul realisasi kehendak anggota serta bersifat realistis dan pragmatis.

b. Penetapan ketentuan operasional yang menyangkut: bidang pegelolaan keuangan,

\section{Segi pengawasan}

Agar rencana koperasi dapat tercapai dengan baik, maka perlu adanya pengawasan yang intensif, baik pengawasan manajemen oleh Pengurus, pengawasan melekat oleh Manajer dan kepala-kepala bagian unit usaha maupun pengawasan oleh Pengawas Koperasi. Khusus mengenai pemeriksaan Pengawas an Koperasi, perlu diketahui hal-hal sebagai berikut.

a. Pengawasan terhadap program kerja, rencana Anggaran Pendapatan dan Belanja.

b.Melaksanakan pemeriksaan dengan baik sesuai dengan ketentuan.

1) Bersikap bebas dan tidak terpengaruh oleh Pengurus, karena Pengawas mempunyai kedudukan yang sejajar dengan Pengurus.

2) Menguasai akuntansi yang dikerjakan oleh koperasi. 
3) Menguasai teknis-teknis pelaksanaan pemeriksaan.

c. Segera membuat laporan hasil pemeriksaan disertai dengan saran-saran perbaikan.

\section{Segi penerapan sanksi}

Jika terjadi kasus penyelewengan dalam koperasi, Pengurus harus tegas dan cepat dalam mengupayakan penyelesaiannya, sebab apabila penanganannya raguragu dan dibiarkan, maka terjadinya tindak negatif ini tidak akan berkurang tetapi dapat semakin berkembang. 


\section{BAB 3 AKUNTANSI KOPERASI BERDASARKAN}

PSAK NO 27

Sesuai dengan PSAK No 27 tentang Akuntansi Koperasi tahun 1996, Pengurus bertanggung jawab dan wajib melaporkan kepada rapat anggota segala sesuatu yang menyangkut tata kehidupan koperasi. Pemakai utama dari laporan keuangan koperasi adalah para anggota koperasi itu sendiri beserta pejabat koperasi. Selain anggota juga calon anggota koperasi, bank, kreditur dan kantor pajak.

\subsection{Perubahan Pernyataan Standar Akuntansi Keuangan (PSAK) No.27}

Laporan Keuangan Koperasi

1. Meliputi neraca, PHU, laporan perubahan kas, laporan promosi ekonomi anggota, dan catatan atas laporan keuangan.

2. Informasi yang disajikan dalam Neraca meliputi aset, kewajiban, dan ekuitas koperasi pada waktu tertentu.

3. PHU memuat hasil usaha dengan anggota dan laba atau rugi kotor dengan nonanggota. 
4. Laporan arus kas menyajikan informasi mengenai peruubahan kas yang meliputi saldo awal kas, sumber penerimaan kas, pengeluaran as, dan saldo akhir kas pada periode tertentu.

5. Laporan promosi ekonomi anggota adalah laporan yang memperlihatkan manfaat ekonomi yang diperoleh anggota koperasi selama satu tahun tertentu. Laporan tersebut mencakup empat unsur, yaitu:

a. Manfaat ekonomi dari pembelian barang atau pengadaan jasa bersama;

b. Manfaat ekonomi dari pemasaran dan pengolahan bersama;

c. Manfaat ekonomi dari simpan pinjam lewat koperasi;

d. Manfaat ekonomi dalam bentuk pembagian sisa hasil usaha.

6. Catatan pengungkapan (disclosures) berisi:

a. Di dalam catatan atas Perlakuan akuntansi berisi tetntang transaksi hasil dari pendapatan dan beban yang berasal dari anggota dan non anggota dapat diakui. Selain itu bagaimana koperasi dapat menilai asset tetap terhadap persediaan, piutang dll. Dan 
bagaimana dasar penetapan harga pelayanan kepada anggota dan nonanggota.

b. Memberikan informasi berupa 1) semua kegiatan utama koperasi baik yang telah dilakukan, 2) pengembangan SDM anggota yang lebih baik sehingga tercipta lapangan usaha baru untuk anggota. 3) Mengikuti semua persyaratan yang ada dalam koperasi, 4) Mengelompokkan piutang dan utang, 5) dana hibah yang diperoleh tidak boleh digunakan untuk pembelian asset semua, 6)Pembagian SHU (anggota dan nonanggota), penggunaan cadangan harus sesuai dengan keputusan yang ada dalam RAT. 


\section{BAB 4. PERSAMAAN DAN SIKLUS AKUNTANSI}

\subsection{Pengertian Akuntansi}

Akuntansi berdasarkan implementasi pada manajemen, menghasilkan system informasi dan teknik prosedur pembukuan dari transaksi keuangan yang dilakukan oleh koperasi

\section{Akuntansi merupakan sistem informasi}

Akuntansi adalah suatu sistem informasi, yang digunakan oleh pihak-pihak yang berkepentingan dalam koperasi untuk pegambilan keputusan. Pihakpihak yang berkepentingan tersebut adalah, pihak manajemen (Pengurus, Pengawas, dan Manajer), pemilik (anggota koperasi), pemerintah (Dinas Koperasi dan UKM, Instansi Pajak, dan lain-lain), dan pihak Kreditur (Bank, BUMN, dan lain-lain).

2. Teknik prosedur pembukuan dari transaksi keuangan koperasi.

Teknis prosedur untuk mencatat, mengklasifikasikan, mengikhtisarkan, dan melaporkan dalam bentuk laporan keuangan transaksi yang telah dilaksanakan 
oleh suatu badan usaha koperasi, dan akhirnya menginterprestasi laporan-laporan tersebut.

\subsection{Sistem Informasi Akuntansi}

Keuangan koperasi dilaporkan secara periodik dapat memberikan informasi yang berupa;

1. informasi mengenai simpanan anggota dan non anggota dan kewajiban serta modal koperasi

2. Keuntungan yang di dapat koperasi berdasarkan informasi dari sumber modal yang timbul dari aktivitas koperasi

3. Sebagai dasar Analisa koperasi untuk mengestimasi kemampuan koperasi dalam menghasilkan laba.;

4. informasi dari aktivitas pembelanjaan investasi;

5. Mengikuti informasi penting dalam mengambil kebijakasanaan akuntansi.

Penyajian Laporan Keuangan pada pihak yang membutuhkan tidak cukup memberikan informasi yang diperlukan oleh semua pihak terkait dengan kegiatan usaha koperasi, yang tidak dapat diperoleh dari Laporan tersebut. 


\subsection{Teknik Prosedur Pembukuan Transaksi Keuangan Koperasi dalam akuntansi}

Tahap-tahap teknik prosedur pembukuan transaksi keuangan koperasi, dalam organisasi sebagai berikut:

1. Pencatatan (recording)

Tahap pencatatan yaitu secara kronologis (berdasarkan urutan waktu) mencatat semua transaksi keuangan yang terjadi ke dalam bukti-bukti transaksi koperasi dan membukukan ke dalam "jurnal"

2. Pengklasifikasian (classifying)

Tahap Pengelompokkan yaitu Mengelompokkan atau menggolongkan transaksi yang sejenis kedalam satu rekening (Buku Besar). Tahap ini memindahkan catatan jurnal ke rekening buku besar yang di sebut dengan posting.

3. Mengikhtisarkan (sunmarizing)

Tahap mengikhtisarkan yaitu merekap saldo ada dalam rekening buku besar sehingga memudahkan penyajian Laporan Keuangan :

a. Neraca yang terdiri atas aset, kewajiban, dan kckayaan bersih yang disusun secara komparatif, 
b. Laporan Laba Rugi yang meliputi Pendapatan Usaha, HPP, biaya-biaya dan sisa hasil usaha pada periode tertentu.

c. Catatan Atas Laporan Keuangan yang merekap nilai perincian dari Neraca dan Perhitungan Hasil Usaha

d. Laporan Arus Kas merupakan laporan yang berasal dari mana sumber dana (kas) masuk dan digunakan untuk apa pada suatu periode tertentu.

4. Pelaporan (reporting)

Tahap melaporkan yaitu memberikan laporan dari hasil data yang telah diolah secara wajar.

5. Menginterpretasikan (interpreting)

Tahap Menganalisa yaitu kegiatan menganalisis Laporan Keuangan yang dihasilkan sehingga dapat diambil suatu kebijakan dari laporan tersebut.

\subsection{Fungsi Akuntansi}

Selain berfungsi sebagai media informasi dan keuangan, akuntansi koperasi berfungsi pula untuk;

a. Keberhasilan koperasi ditentukan dari Kreteria dalam perhitungan hasil usaha; 
b. Sistem dan prosedur diciptakan guna pengamanan dan pengawasan harta kekayaan yang dimiliki koperasi dalam mencegah penyimpangan, penyelewengan, dan pemborosan;

c. Penetapan Hak pemilik/anggota peminjam, pemerintah, dan lain lain dalam koperasi;

d. Menilai efisiensi efisiensi hasil usaha dan biaya.

e. Membantu dalam manajemen koperasi dalam rangka penyusunan perencanaan, pengawasan, dan pengambilan keputusan;

f. Mendorong peningkatan efisiensi dalam seluruh kegiatan koperasi; mendorong ketaatan kepada Undang-Undang, Peraturan Pemerintah, Kebjaksanaan dan Prosedur yang telah digariskan oleh Rapat Anggota Tahunan (RAT) pengurus dan manajer;

\subsection{Persamaan Akuntansi}

Laporan posisi keuangan terdiri dari dua sisi yaitu Debit yang berisi daftar asset yang dimiliki koperasi dan sisi Kredit berisi kewajiban/hutang dan modal. 
NERACA

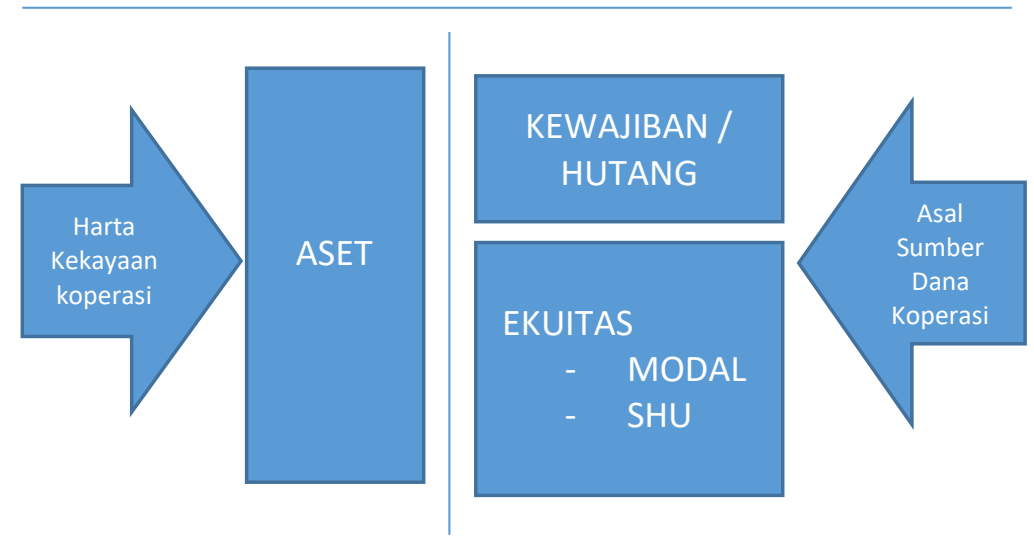

Gambar 4.1. Format Neraca

Aset merupakan kumpulan dari kekayaan koperasi yang akan digunakan untuk memperoleh penghasilan tahun berjalan atau sebelumnya.

Kewajiban/Hutang adalah kewajiban koperasi untuk membayar kepada pihak lain sejumlah uang/barang/jasa dimasa depan akibat transaksi sebelumnya.

Ekuitas merupakan sumber dana koperasi yang berasal dari dalam koperasi (anggota) dan luar koperasi dan laba usaha yang diperoleh koperasi

Aset atau harta koperasi dapat berupa uang tunai/kas, piutang, peralatan kantor, mesin, bangunan, tanah dll. Untuk mendapatkan asset, kopersi dapat melakukan 
dengan membeli dari setoran anggota atau dari hutang atau pinjam dari tempat lain. Jika pembelian asset itu menggunakan dana dari pinjaman pihak lain maka dalam neraca akan terlihat bahwa hutang koperasi bertambah sejumlah harga asset. Karena itu seluruh transaksi Akuntansi Koperasi perlu dipahami dengan baik rumus persamaan akuntansi di bawah ini. Secara garis besar dan sederhana, agar tidak menimbulkan keraguan dalam melakukan jurnal/ analisis transaksi atau mendebit dan mengkredit transaksi yang bersangkutan.

Demikian pula apabila analisis Debit dan Kredit ini menggunakan Kode Akun, tentu akan dapat membantu mempercepat Kode Akun mana yang harus didebit dan mana yang harus dikredit. Diharapkan dengan memahami rumus tersebut, kita akan dapat menganalisis Debit dan Kredit dengan benar:

Rumus Pokok:

\section{Harta/Aset = Kewajiban + Kekayaan Bersih $/$ Ekuitas}

Transaksi-transaksi yang harus didebet dan transaksi mana yang harus dikredit, merupakan rumus:

\begin{tabular}{|l|l}
\hline Debit & Kredit
\end{tabular}




\begin{tabular}{l|l|}
$\begin{array}{l}\text { 1. Harta bertambah } \\
\text { 2. Beban bertambah }\end{array}$ & $\begin{array}{l}\text { 1. Harta berkurang } \\
\text { 3. Kewajiban berkurang }\end{array}$ \\
$\begin{array}{l}\text { 2. Beban berkurang } \\
\text { 3. Kekayaan bersih } \\
\text { berkurang }\end{array}$ & $\begin{array}{l}\text { 4. Kekayaan bertambah } \\
\text { bertambah bersih }\end{array}$ \\
5. Pendapatan berkurang & 5. Pendapatan bertambah
\end{tabular}

\section{SIKLUS AKUNTANSI KOPERASI}

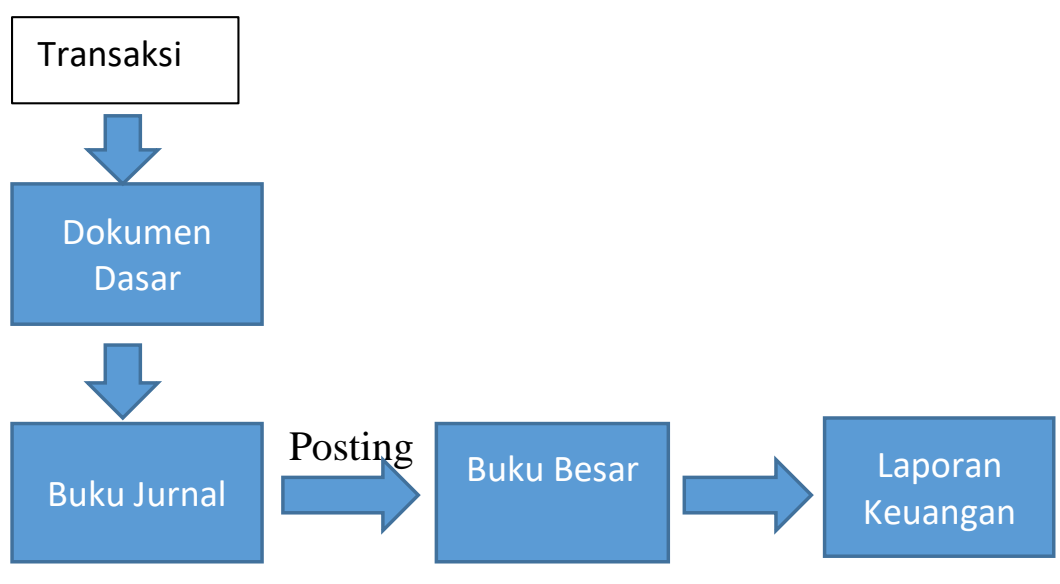

Penjelasan :

1. Proses Akuntansi Dari Dokumen-Dokumen Dasar sampai dengan Laporan Keuangan untuk koperasi Jasa Keuangan (Simpan Pinjam)

TAHAP I 
Harus ada dokumen-dokumen dasar, yang biasa disebut dengan bukti pendukung, yaitu bukti tambahan / pelengkap dari bukti pembukuan dalam melakukan transaksi yang digunakan sebagai dasar pembukuan antara lain:

- $\quad$ Anggta masuk menjadi koperasi;

- $\quad$ kontrak pinjaman;

- $\quad$ instruksi angkutan;

- dan lain sebagainya.

\section{TAHAP II}

Di dalam proses selanjutnya, setiap hari dicatat dan dianalisis /dijurnal pada Bukti-Bukti Akuntansi Koperasi.

Sesuai dengan kebutuhan sistem akuntansi koperasi, maka bukti pembukuan yang tersedia adalah sebagai berikut.

a) Bukti Penerimaan Kas/Bank

Bukti ini dipergunakan untuk membukukan setiap jenis transaksi di mana koperasi menerima secara Kas atau melalui Bank.

b) Bukti Pengeluaran Kas/Bank

Bukti ini dipergunakan untuk membukukan setiap jenis transaksi yang harus dibayar secara Kas atau melalui Bank 
c) Bukti Pembelian/Penerimaan Barang Bukti ini dipergunakan untuk membukukan setiap jenis transaksi pembelian atau penerimaan barang,

d) Bukti Penjualan/Pengeluaran Barang Bukti ini dipergunakan untuk membukukan setiap jenis transaksi penjualan atau pengeluaran barang,

e) Bukti Memorial

Bukti ini dipergunakan untuk membukukan transaksi yang tidak dapat diklasifkasikan ke dalam bukti-bukti pembukuan tersebut di atas.

\section{TAHAP III}

Dari hasil penganalisisan / penjurnalan bukti-bukti akuntansi kemudian dilanjutkan membukukan ke buku jurnal secara kronologis menurut jenisnya. 
Jenis Buku Jurnal yang digunakan adalah sebagai berikut.

a) Jurnal Penerimaan Kas

Jurnal ini dipergunakan untuk mencatat transaksi penerimaan secara tunai dalam kegiatan usaha koperasi.

b) Jurnal Pengeluaran Kas

Jurnal ini dipergunakan untuk mencatat transaksi pengeluaran secara tunai dari kegiatan usaha koperasi,.

c) Jurnal Pembelian

Jurnal ini dipergunakan untuk mencatat transaksi pembelian barang dagangan secara kredit.

d) Jurnal Penjualan

Jurnal ini dipergunakan untuk mencatat transaksi penjualan barang dagangan secara kredit.

e) Jurnal Memorial

Buku jurnal ini dipergunakan untuk mencatat transaksi yang tidak ada hubungannya dengan keempat bukti akuntasi koperasi terdahulu.

\section{TAHAP IV}

Setelah selesai melakukan Pencatatan pada rekapitulasi buku jurnal, maka proses selanjutnya adalah memposting ke Buku Besar yang bersangkutan sebulan sekali. Buku 
Besar terdiri dari bermacam-macam akun/rekening dan merupakan sumber data untuk menyusun laporan keuangan, yaitu Neraca, Laporan Perhitungan Hasil Usaha, Laporan Arus Kas serta Laporan Perubahan Kekayaan Bersih.

\section{TAHAP V}

Untuk mempermudah penyusunan Laporan Keuangan biasanya dilakukan dengan membuat Neraca Lajur. Necara Lajur terdiri dari beberapa kolom, yaitu:

a. Kolom Neraca Sisa/Percobaan

Kolom neraca sisa, diisi dari saldo-saldo masing-masing buku besar.

b. Kolom Penyesuaian

Kolom penyesuaian, untuk mencatat data yang perlu diadakan penyesuaian pada akhir periode pembukuan.

c. Kolom Neraca Setelah Penyesuaian

Kolom ini diisi dari hasil penjumlahan atau pengurangan antara neraca sisa dengan penyesuaian.

d. Kolom Perhitungan Hasil Usaha

Kolom ini mengelompokkan Akun-Akun yang berhubungan dengan sisa hasil usaha (nominal accounts) yang berada di kolom neraca setelah penyesuaian. 
e. Kolom Neraca

Kolom neraca, mengelompokknn Akun akun yang, berhubungan dengan neraca (real account) yang berada di kolom neraca setelah penyesuaian.

Setelah Neraca Lajur selesai dibuat, dan Laporan Keuangan sudah siap untuk disusun, maka perlu dilakukan pembuatan "Jurnal Penutup". Pembuatan Jurnal Penutup dimaksudkan untuk menutup semua akun pendapatan/penjualan dan beban/harga pokok penjualan menjadi nol.

Jurnal Penutup adalah sebagai berikut;

1. Menutup semun Akun pendapatan/ penjualan, antara lain;

Penjualan $\operatorname{XXX}$

Pendapatan Jasa XXX

Pendapatan lain-lain usaha XXX

Pendapatan luar usaha XXX

Pendapatan luar biasa XXX

S.H.U tahun berjalan XXX

2. Menutup semua Akun beban/harga pokok penjuslan, antara lain;

S.H.U tahun berjalan XXX 
Harga pokok penjualan $\quad-\quad$ Xxx

Beban Operasional $\quad$ Xxx

Beban administrasi dan umum _ $\quad$ - $\quad$ Xxx

Beban luar usaha $\quad-\quad$ Xxx

Beban Luar biasa $\quad-\quad$ Xxx

Dengan adanya jurnal penutup maka akan muncul saldo $\mathrm{S}, \mathrm{H}, \mathrm{U}$ tahun berjalan yang akan tampak di dalarn Neraca,

\section{TAHAP VI}

Penyusunan Laporan Keuangan merupakan tahapan terakhir dari proses akuntansi,

Laporan Keuangan koperasi dapat dibagi menjadi 5 bagjan, yaitu:

a. Neraca

Neraca merupakan gambaran mengenai posisi keuangan koperasi pada saat tertentu misalnya posisi per 31 Desember 200X,

b. Laporan Perhitungan Hasil Usaha

Perhitungan hasil usaha merupakan gambaran mengenai hasil usaha koperasi dalam satu periode tertentu misalnya (satu) tahun.

c. Catatan Atas Laporan Keuangan 
Catatan atas laporan keuangan merupakan bagian dari laporan keuangan, karena menjelaskan tentang perubahanperubahan akuntansi dalam satu periode yang memengaruhi posisi keuangan dan hasil usaha koperasi.

d. Laporan Arus Kas

Laporan Arus Kas merupakan perubahan posisi keuangan yang mengikhtisarkan aktivitas pembiayaan dan investas suatu koperasi termasuk kemampuan koperasi menghasilkan dana usaha selama periode bersangkutan.

e. Laporan Ikhtisar Perubahan Posisi Kekayaan Bersih Laporan tersebut merupakan perubahan posisi kekayaan bersih dibandingkan dengan akhir tahun buku tahun sebelumnya

2. Proses Akuntansi dari Dokumen-Dokumen Dasar sampai Sub-Buku Besar

Suatu Akun/rekening buku besar dapat dibuatkan rinciannya apabila jumlahnya cukup banyak, dan rincian itu biasanya dilakukan dengan cara membuat sub-buku besar yang berbentuk Akun / rekening. Di samping itu pada setiap periode (misal, bulanan) saldo buku besar merupakan Akun kontrol atas kebenaran saldo yang ada 
dalam sub-buku besar. Agar sub-buku besar dan buku besar dapat saling mengontrol, maka diperlukan 2 (dua) syarat, yaitu:

a) Yang melaksanakan Pencatatan Sub-Buku Besar dan Buku Besar harus petugas yang berbeda.

b) Dasar pencatatannya harus bersumber dari bukti pembukuan yang sama.

Beberapa Akun yang perlu dibuatkan Sub-Buku Besar, antara lain sebagai berikut.

a. Sub-Buku Besar Kas

b. Sub-Buku Besar Piutang Anggota

d. Sub-Buku Besar Piutang Bukan Anggota

e. Sub-Buku Besar Persediaan

f. Sub-Buku Besar Simpanan Pada Koperasi

g. Sub-Buku Besar Aset Tetap

h. Sub-Buku Besar Utang Anggota

i. Sub-Buku Besar Utang Bukan Anggota

j. Sub-Buku Besar Simpanan Dari Anggota

k. Sub-Buku Besar Penjualan

1. Sub-Buku Besar Pendapatan Jasa

m. Sub-Buku Besar Pembelian

n. Sub-Buku Besar Beban Operasional 
Cara Membukukan dan Melaporkan Neraca dan Perhitungan Hasil Usaha

\begin{tabular}{|c|c|c|c|}
\hline b. & $\begin{array}{ll}\text { Jenis Data/ } & \text { Dransaksi }\end{array}$ & Uraian & $\begin{array}{l}\text { Metode Pencatatan } \\
\text { dan Penilaian }\end{array}$ \\
\hline 1 & Harta Lancar & $\begin{array}{l}\text { Adalah harta koperasi } \\
\text { yang dipakai dalam } \\
\text { jangka waktu siklus } \\
\text { usaha } \\
\text { koperasi/biasanya } 1 \\
\text { tahun. termasuk dalam } \\
\text { golongan ini; } \\
\text { - Kas } \\
\text { - Bank } \\
\text { - Piutang } \\
\text { - Persediaan barang } \\
\text { dagangan } \\
\text { - Uang muka }\end{array}$ & $\begin{array}{l}\text { Dicatat dan } \\
\text { dilaporkan tergantung } \\
\text { syarat-syarat dari } \\
\text { pada masing-masing } \\
\text { unsur harta lancar } \\
\text { yang bersangkutan }\end{array}$ \\
\hline 10 & Kas dan Bank & $\begin{array}{l}\text { Adalah golongan harta } \\
\text { lancar yang terdiri dari; } \\
\text { - Uang kertas } \\
\text { - Uang logam } \\
\text { - Cek } \\
\text { - Saldo giro bank }\end{array}$ & $\begin{array}{lr}\begin{array}{l}\text { Dicatat } \\
\text { dilaporkan }\end{array} & \text { dan } \\
\text { berdasarkan } & \text { nilai } \\
\text { yang tertera } & \text { pada } \\
\text { uang kertas, } & \text { uang } \\
\text { logam, cek dan } & \text { saldo } \\
\text { giro bank. } & \end{array}$ \\
\hline 30 & $\begin{array}{l}\text { Piutang } \\
\text { Anggota }\end{array}$ & $\begin{array}{l}\text { Adalah goongan harta } \\
\text { lancar yang berupa } \\
\text { tagihan koperasi } \\
\text { kepada anggota yang } \\
\text { akan diterima dalam } \\
\text { jangka waktu siklus }\end{array}$ & $\begin{array}{l}\text { Dicatat menurut } \\
\text { jumlah transaksi dan } \\
\text { dilaporkan } \\
\text { berdasarkan jumlah } \\
\text { tagihan yang dapat } \\
\text { direalisasi }\end{array}$ \\
\hline
\end{tabular}




\begin{tabular}{|c|c|c|c|}
\hline & & $\begin{array}{lll}\text { usaha } & \text { koperasi } & 1 \\
\text { tahun. } & & \end{array}$ & $\begin{array}{lr}\text { penerimaannya. Atau } \\
\text { jumlah } & \text { tagihan } \\
\text { menurut } & \text { bukti } \\
\text { dikurangi penyisihan } \\
\text { piutang tak tertagih. } \\
\text { Keduanya harus } \\
\text { ditampakan, bukan } \\
\text { jumlah nettonya. }\end{array}$ \\
\hline 15 & $\begin{array}{l}\text { Persediaan } \\
\text { barang dagang }\end{array}$ & $\begin{array}{l}\text { Adalah goongan harta } \\
\text { lancar yang berupa } \\
\text { barang-barang yang } \\
\text { dibeli oleh koperasi } \\
\text { untuk dijual kembali. } \\
\text { Termasuk dalam } \\
\text { kelompok ini; } \\
\text { - Untuk usaha } \\
\text { dagang: persediaan } \\
\text { barang dagang } \\
\text { - Untuk usaha } \\
\text { industry: bahan } \\
\text { baku } \\
\text { Barang dalam proses } \\
\text { Barang jadi }\end{array}$ & $\begin{array}{l}\text { Dicatat berdasarkan } \\
\text { harga beli, (cost dan } \\
\text { dilaporkan } \\
\text { berdasarkan pilihan } \\
\text { metode harga pokok } \\
\text { secara konsisten: } \\
\text { - FIFO } \\
\text { - LIFO } \\
\text { - Harga rata-rata }\end{array}$ \\
\hline 71 & Uang muka & $\begin{array}{l}\text { Adalah golongan harta } \\
\text { lancar yang berupa } \\
\text { biaya-biaya yang } \\
\text { dibayar lebih dahulu } \\
\text { yang pembebanannya } \\
\text { disesuaikan dengan } \\
\text { masa penggunaannya } \\
\text { missal; } \\
\text { - Uang muka asuransi } \\
\text { - Uang muka sewa }\end{array}$ & $\begin{array}{l}\text { Dicatat berdasarkan } \\
\text { saat dan jumlah yang } \\
\text { dibayarkan dan } \\
\text { dilaporkan } \\
\text { berdasarkan sisa uang } \\
\text { muka yang belum } \\
\text { diangsur } \\
\text { pembebanannya } \\
\text { sebagai biaya } \\
\text { periodic. }\end{array}$ \\
\hline
\end{tabular}




\begin{tabular}{|c|c|c|}
\hline & $\begin{array}{l}\text { - Uang muka } \\
\text { pembelian, dan lain- } \\
\text { lain }\end{array}$ & \\
\hline $\begin{array}{l}\text { Investasi jangka } \\
\text { panjang }\end{array}$ & $\begin{array}{lr}\text { Adalah } & \text { suau } \\
\text { penanaman harta } & \text { jangka panjang (lebih } \\
\text { dari satu tahun) dalam } \\
\text { bentuk saham-saham, } \\
\text { deposito berjangka, } \\
\text { asuransi dan lain-lain. } \\
\text { Investasi jangka } \\
\text { panjang adalah } \\
\text { penyertaan modal pada } \\
\text { suatu koperasi untuk } \\
\text { maksud; } \\
\text { - Kelancaran produksi } \\
\text { - Pemasaran }\end{array}$ & 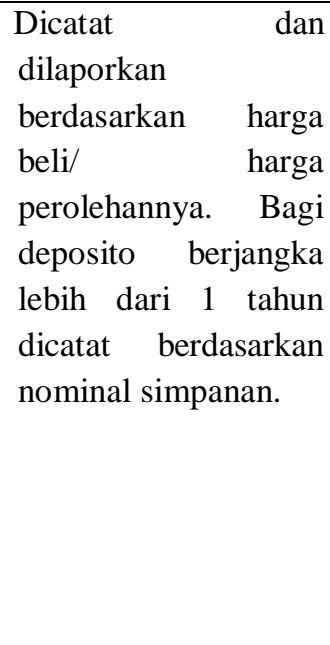 \\
\hline Harta tetap & 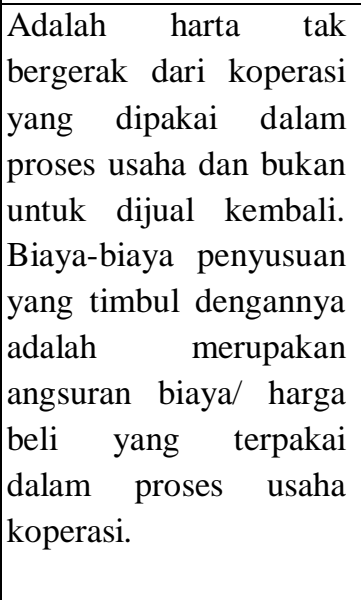 & $\begin{array}{l}\text { Dicatat berdasarkan } \\
\text { harga beli dan } \\
\text { dilaporkan } \\
\text { berdasarkan harga } \\
\text { beli dikurangi dengan } \\
\text { akumulasi penyusutan } \\
\text { menurut pilihan } \\
\text { metode secara } \\
\text { konsisten: } \\
\text { - Metode garis lurus } \\
\text { - Metode saldo } \\
\text { menurun } \\
\text { - Metode produksi }\end{array}$ \\
\hline $\begin{array}{l}\text { Kewajiban } \\
\text { lancar/kewajiban } \\
\text { jangka pendek }\end{array}$ & $\begin{array}{l}\text { Adalah utang koperasi } \\
\text { dari pihak ketiga harus } \\
\text { dibayar dalam jangka }\end{array}$ & $\begin{array}{lr}\text { Dicatat } & \text { dan } \\
\text { dilaporkan } & \\
\text { berdasarkan } & \text { jumlah }\end{array}$ \\
\hline
\end{tabular}




\begin{tabular}{|c|c|c|c|}
\hline & & $\begin{array}{ll}\text { waktu siklus } & \text { usaha } \\
\text { koperasi/1 } & \text { tahun. } \\
\text { termasuk } & \text { dalam } \\
\text { kelompok ini; } & \\
\text { - Utang dagang } & \\
\text { - Utang biaya } & \\
\text { - Utang pajak } & \end{array}$ & $\begin{array}{l}\text { transaksi dan akan } \\
\text { dibayar dalam waktu } \\
1 \text { tahun atau dalam } \\
\text { jangka waktu siklus } \\
\text { usaha koperasi. }\end{array}$ \\
\hline & $\begin{array}{l}\text { Kewajiban } \\
\text { jangka panjang }\end{array}$ & \begin{tabular}{lrr} 
Adalah & salah & satu \\
sumber harta kekayaan \\
koperasi dari & pihak \\
ketiga & berupa \\
pinjaman & jangka \\
panjang lebih & dari 1 \\
tahun dan & disertai \\
dengan & beban \\
\%/bunga. Termasuk \\
dalam kelompok ini: \\
\multicolumn{3}{c}{ Utang } \\
\multicolumn{3}{c}{ investasi }
\end{tabular} & 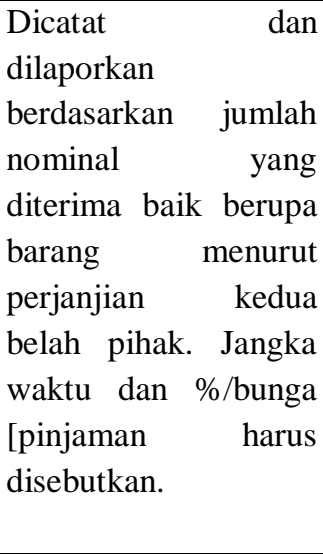 \\
\hline & Kekayaan bersih & $\begin{array}{lr}\text { Adalah } & \text { sumber } \\
\text { harta kekayaan koperasi } \\
\text { yang terdiri } & \text { dari } \\
\text { simpanan } & \text { pokok, } \\
\text { simpanan } & \text { wajib } \\
\text { anggota, } & \text { simpanan } \\
\text { sukarela, cadangan, sisa } \\
\text { hasil usaha dan lain- } \\
\text { lain. }\end{array}$ & $\begin{array}{l}\text { Dicatat dan } \\
\text { dilaporkan } \\
\text { berdasarkan jumlah } \\
\text { nilai setoran dari } \\
\text { anggota dan jumlah } \\
\text { uang yang diperoleh. }\end{array}$ \\
\hline 2 & $\begin{array}{l}\text { Pendapatan } \\
\text { usaha }\end{array}$ & $\begin{array}{l}\text { Adalah } \\
\text { bertambah/naiknya } \\
\text { harta koperasi yang } \\
\text { diakibatkan dari usaha } \\
\text { penjualan barang/jasa }\end{array}$ & $\begin{array}{l}\text { Dicatat dan } \\
\text { dilaporkan } \\
\text { berdasarkan jumlah } \\
\text { menurut bukti dan } \\
\text { saat kejadiannya }\end{array}$ \\
\hline
\end{tabular}




\begin{tabular}{|c|c|c|c|}
\hline & & $\begin{array}{l}\text { koperasi dalam suatu } \\
\text { periode baik kredit } \\
\text { maupun tunai. }\end{array}$ & dalam suatu periode. \\
\hline 0 & Beban usaha & $\begin{array}{l}\text { Adalah pengeluaran- } \\
\text { pengeluaran koperasi } \\
\text { atau turunnya nilai } \\
\text { harta koperasi sebab } \\
\text { dari kegiatan usaha } \\
\text { koperasi memperoleh } \\
\text { pendapatan/penjualan } \\
\text { barang/jasa dalam } \\
\text { periode. Transaksi } \\
\text { dalam transaksi ini: } \\
\text { - Harga pokok } \\
\text { penjualan } \\
\text { - Beban usaha/beban } \\
\text { operasional } \\
\text { - Beban administrasi } \\
\text { dan umum } \\
\text { - Beban lain-lain } \\
\text { - Beban luar biasa dan } \\
\text { lain-lain }\end{array}$ & $\begin{array}{lr}\text { Dicatat } & \text { dan } \\
\text { dilaporkan } & \\
\text { berdasarkan jumlah } \\
\text { yang } \\
\text { dibayarkan/terpakai } \\
\text { sejalan dengan } \\
\text { periode } \\
\text { penjualan/pendapatan. }\end{array}$ \\
\hline
\end{tabular}




\section{BAB 5 PERMODALAN}

\subsection{MODAL KOPERASI}

Modal koperasi terdiri dari :

3. Modal sendiri, berasal dari

a) Simpanan Pokok,

b) Simpanan Wajib

c) Dana cadangan

d) serta sumber-sumber lain (hibah)

4. Modal Pinjaman, berasal dari

a) Anggota

b) Koperasi lainnya dan atau anggotanya

c) Bank dan Lembaga keuangan lainnya

d) Sumber lain yang sah

Simpanan anggota terdiri dari :

b) Simpanan pokok yaitu jumlah nilai uang yang disetorkan ke koperasi pada saat awal menjadi anggota dan tidak boleh diambil selama menjadi anggota koperasi.

c) Simpanan wajib yaitu simpanan yang wajib disetorkan oleh anggota dalam waktu dan kesempatan tertentu, 
misalnya setiap bulan (baik anggota yang melakukan peminjaman maupun tidak)

d) Simpanan sukarela yaitu simpanan anggota dan bukan anggota atas kehendak sendiri dan tidak terikat nominalnya. Simpanan ini dapat diambil sewaktuwaktu.

\subsection{PERHITUNGAN HASIL USAHA KOPERASI}

Berdasarkan undang-undang perkoperasian no 25 tahun 1992 Sisa Hasil Usaha (SHU) merupakan pendapatan koperasi yang diperoleh dalam satu tahun buku dikurangi dengan biaya, penyusutan dan kewajiban lainnya termasuk pajak dalam tahun buku yang bersangkutan. SHU bukan merupakan satu-satunya alat pengukur bagi manfaat keanggotaan koperasi dan prestasi pengurus. Karena merupakan hasil dari aturan dan prosedur akuntansi yang ditetapkan dalam koperasi dan mencerminkan perubahan kekayaan bersih yang dimiliki oleh anggota dan koperasi itu sendiri, yang berasal dari transaksi, kejadian atau keadaan ckonomis yang timbul dari kegiatan usaha. Sisa Hasil Usaha setelah dikurangi dana cadangan, dibagikan kepada anggota sebanding dengan jasa usaha yang 
dilakukan oleh masing-masing anggota dengan koperasi, serta digunakan untuk Pendidikan perkoperasian dan keperluan lain dari koperasi, sesuai dengan keputusan Rapat Aanggota Tahunan. Besarnya pemupukan cadangan ditetapkan dalam RAT. Cadangan koperasi bukan milik anggota koperasi dan tidak boleh dibagikan kepada anggota walaupun di waktu pembubaran. Struktur klaim yang demikian menunjukkan bahwa koperasi mempunyai eksistensi tersendiri, terpisah dengan anggota-anggotanya. Keanggotaan pada koperasi tidak dipindah-tangankan dengan dalih apapun. Jika terjadi kerugian Anggota koperasi tidak akan menanggung seluruhnya. Kerugian hanya dapat dibebankan pada kekayaan koperasi (dalam bentuk cadangan yang telah dipupuk) dan kepada anggota sebesar jumlah tanggungan yang ditetapkan dalam anggaran dasar. Dalam kaitan ini, sisa hasil usaha bukan merupakan perubahan kekayaan dari anggota. Komponen pembagian SHU sesuai dengan undang-undang adalah sebagai berikut: 


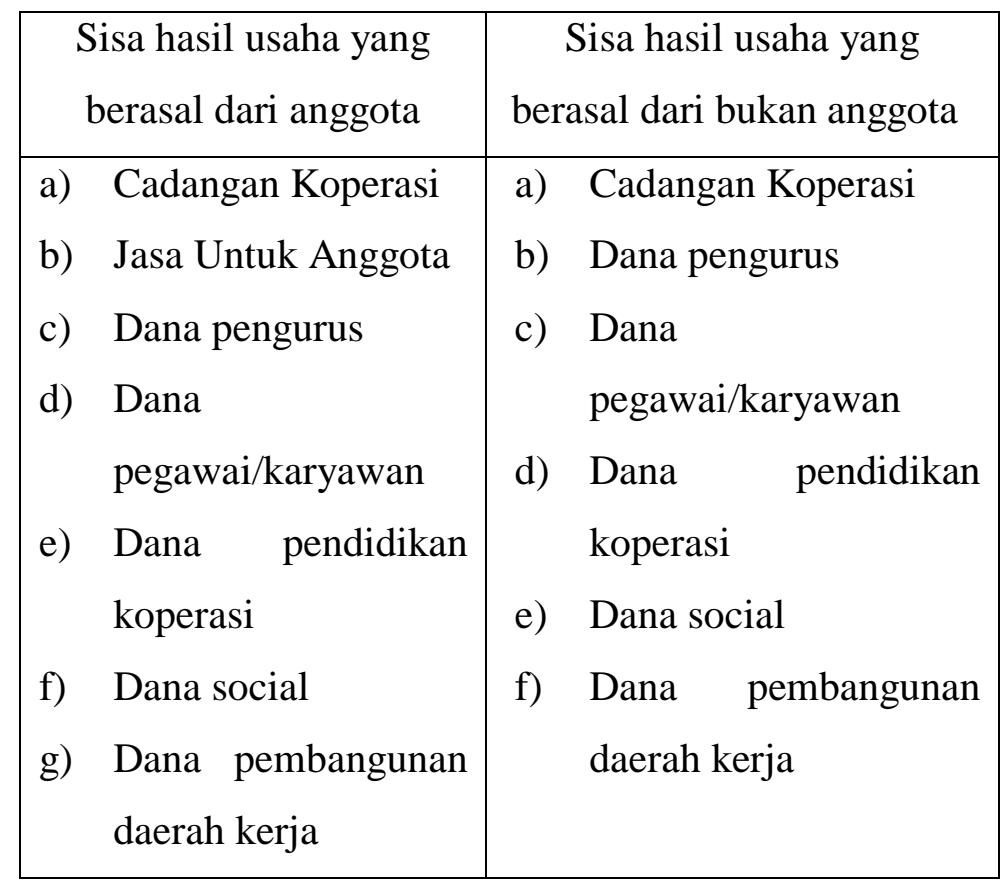

Komponen-komponen tersebut selama belum dicairkan disajikan dalam kelompok kewajiban lancar pada neraca sedangkan cadangan koperasi merupakan bagian sisa hasil usaha yang tidak dibagi dan dapat digunakan untuk memupuk modal sendiri dan menutup kerugian

Rumus pembagian SHU

$\mathrm{SHU} A=\mathrm{JUA}+\mathrm{JMA}$

Keterangan : 
SHU A = Sisa Hasil Usaha anggota

JUA = Jasa Usaha Anggota

JMA = Jasa Modal Anggota

Rumus untuk mengetahui Jasa Modal Anggota (JMA)

$\mathrm{JMA}=\underline{\text { Simpanan Anggota }} \mathrm{X} \%$ jasa modal X SHU Tot simpanan koperasi

Rumus untuk mengetahui Jasa Modal Anggota (JMA)

JUA=Jasa Pinjaman Anggota X\%Jasa modal X SHU Tot Jasa Pinjaman anggota 


\section{BAB 6. APLIKASI AKUNTANSI DAN PENYUSUNAN LAPORAN KEUANGAN}

Koperasi Sejahterah merupakan koperasi Simpan Pnjam yang berdiri tahun 2019 dan sudah Berbadan Hukum. Anggotanya berjumlah 25 orang dengan masing-masing memiliki simpanan pokok sebesar Rp 100.000 dan simpanan wajib Rp. 10.000,-. Modal yang dimiliki koperasi selain berasal dari anggota Untuk mengembangkan modal koperasi, pengurus memberikan pinjaman kepada anggota dengan ketentuan minimal Rp. 500.000, maksimal Rp. 1.000.000,- dan dapat diangsur selama 10 kali. Adapun transaksi selama tahun 2020 adalah sbb:

5 Jan 2020 Menerima iuran pokok dan wajib dari 5 anggota baru (A,B,C,D,E) dan setiap anggota dikenakan biaya administrasi Rp. 10.000,-

10 Peb 2020 Membeli materai 10 lb @6000

15 Peb 2020 Koperasi Memberikan pinjaman kepada A, B, C masing-masing $\mathrm{Rp}$ 500.000.dengan jasa 1,5\% dari pinjaman serta SW bulan Pebruari

15 Maret 2020 Angsuran dan SW bulan maret dari A,B,C sejumlah Rp. 202.500,- 
15 April 2020 D,E menerima pinjaman sejumlah @ Rp. $500.000,-$, diangsur selama 5 bln dan membayar SW 3 bln (peb dan April).

Angsuran dan SW bulan April dari A,B,C sejumlah Rp. 202.500,-

15 Mei 2020 Menerima angsuran dan SW A,B,C,D,E

01 Juni 2020 Menerima SW 25 anggota pendiri koperasi untuk 6 bln (Januari - Juni)

15 Juni 2020 Menerima angsuran dan SW A,B,C,D,E

15 Juli 2020 Menerima simpanan pokok, SW dan administrasi dari Anggota baru F.

Menerima angsuran dan SW dari A,B,C,D,E

15 Agust 2020 Menerima angsuran dan SW A,B,C,D,E bln Agustus

01 Sept 2020 Biiaya transportasi pengurus ke Dinas Koperasi Rp. 50.000,-

15 Sept 2020 Menerima angsuran dan SW A,B,C,D,E bln September dan simpanan sukarela Rp 500.000 dari anggota $\mathrm{C}$.

15 Okt 2020 Menerima angsuran dan SW A,B,C, bln Oktober Beli Meja Kursi seharga Rp 500.000 dan disusutkan selama 5 th. 
15 Nop 2020 Memberikan pinjaman kepada D Rp 750.000.

Menerima angsuran dan SW A,B,C, bln Nop. C mengambil simpanan sukarela Rp 500.000

15 Des 2020 Konsumsi rapat pengurus dan pengawas Rp 100.000,-

Menerima angsuran dan SW A,B,C,D,E bln Desember

Dari transaksi diatas, maka Langkah-langkah yang harus dilakukan oleh bagian keuangan adalah :

Langkah 1.

Pada saat terjadi transaksi kas masuk dan kas keluar bagian keuangan harus membuatkan bukti berupa kuitansi. Pastikan bahwa transaksi tersebut ada buktinya berupa kwitansi, faktur dll.

Langkah 2

Mencatat semua transaksi kedalam jurnal kas masuk dan kas keluar dan jurnal memorial 
a. Jurnal Kas Masuk

\section{KOPERASI SEJAHTERAH \\ JURNAL PENERIMAAN KAS \\ Periode 31 Desember 2020}

\begin{tabular}{|c|c|c|c|c|c|c|c|c|c|c|}
\hline TGL & URAIAN & NA & NB & KAS & PIUTANG & JASA & $\begin{array}{l}\text { SIMP } \\
\text { POKOK }\end{array}$ & $\begin{array}{l}\text { SIMP } \\
\text { WAJIB }\end{array}$ & $\begin{array}{c}\text { SIMP } \\
\text { SR }\end{array}$ & ADM \\
\hline 5 Jan & Angg baru $A, B, C, D, E$ & & & 600.000 & & & 500.000 & 50.000 & & 50.000 \\
\hline 15 Peb & SW peb $A, B, C$ & & & 30.000 & & & & 30.000 & & \\
\hline $15 \mathrm{Mrt}$ & Angs $1 \mathrm{ABC}$, SW Mrt & & & 202.500 & 150.000 & 22.500 & & 30.000 & & \\
\hline \multirow[t]{2}{*}{$16 \mathrm{Apr}$} & Angs 2 ABC, SW Apr & & & 202.500 & 150.000 & 22.500 & & 30.000 & & \\
\hline & SW D,E bln Peb - Apr & & & 60.000 & & & & 60.000 & & \\
\hline \multirow[t]{2}{*}{$15 \mathrm{Mei}$} & Angs 3 ABC, SW Mei & & & 202.500 & 150.000 & 22.500 & & 30.000 & & \\
\hline & Angs $1 \mathrm{D}, \mathrm{E}, \mathrm{SW}$ Mei & & & 250.000 & 200.000 & 30.000 & & 20.000 & & \\
\hline 01 Juni & SW 25 Angg Jan-Juni & & & 1.500 .000 & & & & 1.500 .000 & & \\
\hline \multirow[t]{2}{*}{15 Juni } & Angs $4 \mathrm{~A}, \mathrm{~B}, \mathrm{C}, \mathrm{SW}$ Juni & & & 202.500 & 150.000 & 22.500 & & 30.000 & & \\
\hline & Angs 2 D,E, SW Juni & & & 250.000 & 200.000 & 30.000 & & 20.000 & & \\
\hline $15 \mathrm{Juli}$ & Anggota baru F & & & 120.000 & & & 100.000 & 10.000 & & 10.000 \\
\hline
\end{tabular}




\begin{tabular}{|c|c|c|c|c|c|c|c|c|}
\hline & Angs $5 \mathrm{~A}, \mathrm{~B}, \mathrm{C}$, SW Juli & 202.500 & 150.000 & 22.500 & & 30.000 & & \\
\hline & Angs 3 D,E, SW Juli & 250.000 & 200.000 & 30.000 & & 20.000 & & \\
\hline \multirow[t]{2}{*}{15 Agst } & Angs $6 \mathrm{~A}, \mathrm{~B}, \mathrm{C}, \mathrm{sW}$ Ags & 202.500 & 150.000 & 22.500 & & 30.000 & & \\
\hline & Angs 4 D,E SW Agst & 250.000 & 200.000 & 30.000 & & 20.000 & & \\
\hline \multirow[t]{3}{*}{15 Sep } & Angs 7 A, B, C, sW Sep & 202.500 & 150.000 & 22.500 & & 30.000 & & \\
\hline & Simpanan Sukarela C & 500.000 & & & & & 500.000 & \\
\hline & Angs 5 D,E, SW Sep & 250.000 & 200.000 & 30.000 & & 20.000 & & \\
\hline $15 \mathrm{Okt}$ & Angs $8 \mathrm{~A}, \mathrm{~B}, \mathrm{C}, \mathrm{sW}$ Okt & 202.500 & 150.000 & 22.500 & & 30.000 & & \\
\hline \multirow[t]{2}{*}{$15 \mathrm{Nop}$} & Angs 9 A,B,C, sW Nop & 202.500 & 150.000 & 22.500 & & 30.000 & & \\
\hline & SW Okt - Nop & 20.000 & & & & 20.000 & & \\
\hline \multirow[t]{2}{*}{15 Des } & Angs $10 \mathrm{ABC}$, SW Des & 202.500 & 150.000 & 22.500 & & 30.000 & & \\
\hline & Angs $1 \mathrm{D}$, SW Des & 96.250 & 75.000 & 11.250 & & 10.000 & & \\
\hline \multicolumn{2}{|r|}{ TOTAL } & 6.201 .250 & 2.575 .000 & 386.250 & 600.000 & 2.080 .000 & 500.000 & 60.000 \\
\hline
\end{tabular}


b. Jurnal Kas Keluar (JKK)

\section{KOPERASI SEJAHTERAH \\ JURNAL PENGELUARAN KAS}

Periode 31 Desember 2020

\begin{tabular}{|c|c|c|c|c|c|c|c|c|c|c|}
\hline \multirow{2}{*}{ TGL } & \multirow{2}{*}{ URAIAN } & \multirow{2}{*}{ NA } & \multirow{2}{*}{ NB } & \multirow{2}{*}{ PIUTANG } & \multirow{2}{*}{ B. ORG } & \multirow{2}{*}{$\begin{array}{c}\text { B. } \\
\text { ADM }\end{array}$} & \multirow{2}{*}{$\begin{array}{l}\text { SIMP } \\
\text { SR }\end{array}$} & \multicolumn{2}{|c|}{ LAIN-LAIN } & \multirow[t]{2}{*}{ KAS } \\
\hline & & & & & & & & KET & & \\
\hline 10 Peb & Materai $10 \mathrm{lb}$ & & & & & 60.000 & & & & 60.000 \\
\hline 15 Peb & Pinj $A, B, C$ & & & 1.500 .000 & & & & & & 1.500 .000 \\
\hline $15 \mathrm{Apr}$ & Pinj pada $D, E$ & & & 1.000 .000 & & & & & & 1.000 .000 \\
\hline 01 Sep & ke Dinas Kop & & & & 50.000 & & & & & 50.000 \\
\hline $15 \mathrm{Okt}$ & meja kursi ktr & & & & & & & Ak tetap & 500.000 & 500.000 \\
\hline \multirow[t]{2}{*}{$15 \mathrm{Nop}$} & Pinj pada D & & & 750.000 & & & & & & 750.000 \\
\hline & Suka rela C & & & & & & 500.000 & & & 500.000 \\
\hline 15 Des & Kons rapat & & & & 100.000 & & & & & 100.000 \\
\hline \multicolumn{4}{|l|}{ TOTAL } & 3.250 .000 & 150.000 & 60.000 & 500.000 & & 500.000 & 4.460 .000 \\
\hline
\end{tabular}




\section{Langkag 3}

Posting kedalam buku Besar sesuai dengan akun masingmasing dan juga masukkan ke dalam buku besar pembantu (buku piutang sesuai dengan nama anggota masing-masing dan buku hutang sesuai dengan hutang masing-masing).

\section{KOPERASI SEJAHTERAH \\ KARTU ANGGOTA}

Nama : D

Alamat :

Jk.

Waktu :5

Bunga $: 1,5$

Angs :

\begin{tabular}{|l|l|l|l|l|l|l|l|l|}
\hline \multirow{2}{*}{ Tgl } & \multirow{2}{*}{ NB } & \multirow{2}{*}{ Uraian } & \multicolumn{2}{|c|}{ Simpanan } & \multicolumn{2}{c|}{ Pinjaman } & Saldo & Ket \\
\cline { 3 - 9 } & & Ket & Pokok & Wajib & Pokok & Bunga & Pinj & \\
\hline 5 Jan & & & 100000 & 10000 & & & & \\
\hline 16 Apr & & 3 bln & & 30000 & & & 500000 & \\
\hline 15 Mei & Angs1 & & 10000 & 100000 & 15000 & 400000 & \\
\hline 15 Juni & Angs2 & & 10000 & 100000 & 15000 & 30000 & \\
\hline 15 Juli & Angs3 & & 10000 & 100000 & 15000 & 20000 & \\
\hline 15 Ags & Angs4 & & 10000 & 100000 & 15000 & 100000 & \\
\hline 15 Sep & & Angs5 & & 10000 & 100000 & 15000 & 0 & LN \\
\hline 15 Nop & Pinj & & 20000 & - & - & 750000 & \\
\hline 15 Des & Angs1 & & & 75000 & 11250 & & \\
\hline 31 Des & Total & 100.000 & 100.000 & & 86250 & 750000 & \\
\hline
\end{tabular}

Buku Pembantu Piutang dibuat berdasarkan masing-masing nama anggota 
Koperasi Sejahterah

Buku Besar Kas

per 31 Desember 2020

\begin{tabular}{|l|l|r|r|r|r|}
\hline TGL & Keterangan & Ref & \multicolumn{1}{l|}{ Debet } & \multicolumn{1}{l|}{ Kredit } & \multicolumn{1}{l|}{ Saldo } \\
\hline 1 Jan & Saldo awal & NS & & & 2.750 .000 \\
\hline 5 Jan & Pendapatan Adm & JKM & 50.000 & & 2.800 .000 \\
\hline 5 Jan & Angg baru A,B,C,D,E & JKM & 550.000 & & 3.350 .000 \\
\hline 10 Peb & Materai & JKK & & 60.000 & 3.290 .000 \\
\hline 15 Peb & Pinjaman & JKK & & 1.500 .000 & 1.790 .000 \\
\hline 15 Peb & SW peb A,B,C & JKM & 30.000 & & 1.820 .000 \\
\hline 15 Mar & Angs 1 A,B,C, SW Mrt & JKM & 202.500 & & 2.022 .500 \\
\hline 15 Apr & Pinjaman & JKK & & 1.000 .000 & 1.022 .500 \\
\hline 16 Apr & Angs 2 ABC, SW Apr & JKM & 202.500 & & 1.225 .000 \\
\hline & SW D,E bln Peb- April & JKM & 60.000 & & 1.285 .000 \\
\hline 15 Mei & Angs 3 A,B,C, SW Mei & JKM & 202.500 & & 1.487 .500 \\
\hline & Angs 1 D,E, SW Mei & JKM & 250.000 & & 1.737 .500 \\
\hline 01 Juni & SW 25 Angg Jan-Juni & JKM & 1.500 .000 & & 3.237 .500 \\
\hline 15 Juni & Angs 4 A,B,C, SW Juni & JKM & 202.500 & & 3.440 .000 \\
\hline & Angs 2 D,E, SW Juni & JKM & 250.000 & & 3.690 .000 \\
\hline 15 Juli & Anggota baru F & JKM & 120.000 & & 3.810 .000 \\
\hline & Angs5 A,B,C, SW Juli & JKM & 202.500 & & 4.012 .500 \\
\hline & Angs ke 3 D,E, SW Juli & JKM & 250.000 & & 4.262 .500 \\
\hline 15 Ags & Angs 6 A,B,C, SW Ags & JKM & 202.500 & & 4.465 .000 \\
\hline & Angs 4 D,E, SW Agust & JKM & 250.000 & & 4.715 .000 \\
\hline 01 Sep & Transport ke Dinas & JKK & & 50.000 & 4.665 .000 \\
\hline 15 Sep & Angs 7 A,B,C, SW Sep & JKM & 202.500 & & 4.867 .500 \\
\hline & Simpanan Sukarela C & JKM & 500.000 & & 5.367 .500 \\
\hline & Angs 5 D,E, SW Sep & JKM & 250.000 & & 5.617 .500 \\
\hline & & & & & \\
\hline
\end{tabular}




\begin{tabular}{|l|l|r|r|r|r|}
15 Okt & Meja Kursi sec tunai & JKK & & 500.000 & 5.117 .500 \\
\hline 15 Okt & Angs 8 A,B,C, SW Okt & JKM & 202.500 & & 5.320 .000 \\
\hline 14Nop & Pinjaman D & JKK & & 750.000 & 4.570 .000 \\
\hline & Simp Sukarela C & JKK & & 500.000 & 4.070 .000 \\
\hline 15 Nop & Angs 9 A,B,C, SW Nop & JKM & 202.500 & & 4.272 .500 \\
\hline & Konsumsi Rapat & JKK & & 100.000 & 4.172 .500 \\
\hline & SW D Nop - Des & JKM & 20.000 & & 4.192 .500 \\
\hline 15 Des & Ang 10 A,B,C SW Des & JKM & 202.500 & & 4.395 .000 \\
\hline & Angs 1 D, SW Des & JKM & 96.250 & & 4.491 .250 \\
\hline & & & & & \\
\hline & Saldo Ahir 31 Des & & & & 4.491 .250 \\
\hline
\end{tabular}

Koperasi Sejahterah

Buku Besar Piutang

31 Desember 2020

\begin{tabular}{|l|l|l|l|r|r|}
\hline Tanggal & Keterangan & Ref & Debet & Kredit & \multicolumn{1}{l|}{ Saldo } \\
\hline 01 Jan & Saldo Awal & NS & & & 0 \\
\hline 15 Peb & Pinjaman A,B,C & JKK & 1.500 .000 & & 1.500 .000 \\
\hline $15 \mathrm{Mar}$ & Angsuran A,B,C & JKM & & 150.000 & 1.350 .000 \\
\hline $15 \mathrm{Apr}$ & Pinjaman D,E & JKK & 1.000 .000 & & 2.350 .000 \\
\hline $16 \mathrm{Apr}$ & Angs A,B,C & JKM & & 150.000 & 2.200 .000 \\
\hline $15 \mathrm{Mei}$ & Angs A,B,C,D,E & JKM & & 350.000 & 1.850 .000 \\
\hline 15 Juni & Angs A,B,C,D,E & JKM & & 350.000 & 1.500 .000 \\
\hline 15 Juli & Angs A,B,C,D,E & JKM & & 350.000 & 1.150 .000 \\
\hline 15 Ags & Angs A,B,C,D,E & JKM & & 350.000 & 800.000 \\
\hline 15 Sep & Angs A,B,C,D,E & JKM & & 350.000 & 450.000 \\
\hline 15 Okt & Angs A,B,C & JKM & & 150.000 & 300.000 \\
\hline
\end{tabular}




\begin{tabular}{|l|l|r|r|r|r|} 
14 Nop & Pinjaman D & JKK & 750.000 & & 1.050 .000 \\
\hline 15 Nop & Angs A,B,C & & & 150.000 & 900.000 \\
\hline 15 Des & Angs A,B,C,D & JKM & & 225.000 & 675.000 \\
\hline 31 Des & Saldo Akhir & & & & 675.000 \\
\hline
\end{tabular}

Koperasi Sejahterah

Buku Besar Simpanan Pokok

Per 31 Desember 2020

\begin{tabular}{|l|l|l|l|l|r|}
\hline Tgl & Keterangan & Ref & Debet & Kredit & Saldo \\
\hline 01 Jan & Saldo Awal & NS & & & 2.500 .000 \\
\hline 05 Jan & AnggA, B,C,D,E & JKM & & 500.000 & 3.000 .000 \\
\hline 15 Juli & Anggota F & JKM & & 100.000 & 3.100 .000 \\
\hline & & & & & \\
\hline 31 Des & Saldo Akhir & & & & 3.100 .000 \\
\hline
\end{tabular}

Koperasi Sejahterah

Buku Besar Simpanan Sukarela

Per 31 Desember 2020

\begin{tabular}{|l|l|c|l|l|r|}
\hline Tanggal & Keterangan & Ref & Debet & Kredit & Saldo \\
\hline 1 Jan & Saldo Awal & NS & & & - \\
\hline 15 Sep & Anggota C & JKM & & 500.000 & 500.000 \\
\hline 14 Nop & Anggota C & JKK & 500.000 & & - \\
\hline & & & & & \\
\hline 31 Des & Saldo Akhir & & & & - \\
\hline
\end{tabular}


Koperasi Sejahterah

Buku Besar Simpanan Wajib

Per 31 Desember 2020

\begin{tabular}{|l|l|l|l|r|r|}
\hline Tanggal & Keterangan & Ref & Debet & \multicolumn{1}{l|}{ Kredit } & \multicolumn{1}{l|}{ Saldo } \\
\hline 01 Jan & Saldo Awal & NS & & & 250.000 \\
\hline 05 Jan & A,B,C,D,E & JKM & & 50.000 & 300.000 \\
\hline 15 Peb & A,B,C & JKM & & 30.000 & 330.000 \\
\hline 15 Mar & A,B,C & JKM & & 30.000 & 360.000 \\
\hline 15 Apr & A,B,C,D,E & JKM & & 90.000 & 450.000 \\
\hline 15 Mei & A,B,C,D,E & JKM & & 50.000 & 500.000 \\
\hline 01 Juni & 25 Anggota & JKM & & 1.500 .000 & 2.000 .000 \\
\hline 15 Juni & A,B,C,D,E & JKM & & 50.000 & 2.050 .000 \\
\hline 15 Juli & A,B,C,D,E,F & JKM & & 60.000 & 2.110 .000 \\
\hline 15 Ags & A,B,C,D,E & JKM & & 50.000 & 2.160 .000 \\
\hline 15 Sep & A,B,C,D,E & JKM & & 50.000 & 2.210 .000 \\
\hline 15 Okt & A,B,C & JKM & & 30.000 & 2.240 .000 \\
\hline 15 Nop & A,B,C,D & JKM & & 50.000 & 2.290 .000 \\
\hline 15 des & A,B,C,D & JKM & & 40.000 & 2.330 .000 \\
\hline & & & & & \\
\hline 31 Des & Saldo Akhir & & & & 2.330 .000 \\
\hline
\end{tabular}

Koperasi Sejahterah

Buku Besar Pendapatan Jasa

Per 31 Desember 2020

\begin{tabular}{|l|l|l|l|l|l|}
\hline Tanggal & Keterangan & Ref & Debet & Kredit & Saldo \\
\hline 15 Mar & Dari A,B,C & JKM & & 22.500 & 22.500 \\
\hline
\end{tabular}




\begin{tabular}{|l|l|l|l|r|r|} 
15 Apr & Dari A,B,C & JKM & & 22.500 & 45.000 \\
\hline 15 Mei & Dari A,B,C,D,E & JKM & & 52.500 & 97.500 \\
\hline 15 juni & Dari A,B,C D,E & JKM & & 52.500 & 150.000 \\
\hline 15 Juli & Dari A,B,C D,E & JKM & & 52.500 & 202.500 \\
\hline 15 Ags & Dari A,B,C D,E & JKM & & 52.500 & 255.000 \\
\hline 15 Sep & Dari A,B,C D,E & JKM & & 52.500 & 307.500 \\
\hline 15 Okt & Dari A,B,C & JKM & & 22.500 & 330.000 \\
\hline 15 Nop & Dari A,B,C & JKM & & 22.500 & 352.500 \\
\hline 15 Des & Dari A,B,C,D & JKM & & 33.750 & 386.250 \\
\hline 31 Des & Saldo & & & & 386.250 \\
\hline
\end{tabular}

Koperasi Sejahterah

Buku Besar Pendapatan Administrasi

Per 31 Desember 2020

\begin{tabular}{|l|l|l|l|r|r|}
\hline Tanggal & Keterangan & Ref & Debet & Kredit & Saldo \\
\hline 5 Jan & Angg baru & JKM & & 50.000 & 50.000 \\
\hline 15 Juli & Angg baru & JKM & & 10.000 & 60.000 \\
\hline & & & & & \\
\hline 31 Des & Saldo Akhir & & & & 60.000 \\
\hline
\end{tabular}

Koperasi Sejahterah

Buku Besar Beban Organisasi

Per 31 Desember 2020

\begin{tabular}{|l|l|r|l|l|r|}
\hline Tanggal & Keterangan & Ref & Debet & Kredit & Saldo \\
\hline 01 Sep & Transport & JKK & 50.000 & & 50.000 \\
\hline 15 Des & Konsumsi & JKK & 100.000 & & 100.000 \\
\hline & & & & & \\
\hline
\end{tabular}


\begin{tabular}{|l|l|l|l|l} 
31 des $\mid$ Saldo Akhir & & & 150.000
\end{tabular}

Koperasi Sejahterah

Buku Besar Beban Administrasi

Per 31 Desember 2020

\begin{tabular}{|l|l|c|l|l|c|}
\hline Tanggal & Keterangan & Ref & Debet & Kredit & Saldo \\
\hline 10 Peb & Materai & JKK & 60.000 & & 60.000 \\
\hline & & & & & \\
\hline 31 Des & Saldo Akhir & & & & 60.000 \\
\hline
\end{tabular}

Koperasi Sejahterah

Buku Besar Aktiva Tetap

Per 31 Desember 2020

\begin{tabular}{|l|l|l|l|l|l|}
\hline Tanggal & Keterangan & Ref & Debet & Kredit & Saldo \\
\hline 15 Okt & Meja Kursi & JKK & 500.000 & & 500.000 \\
\hline & & & & & \\
\hline 31 Des & Saldo Akhir & & & & 500.000 \\
\hline
\end{tabular}

\section{Langkah 4}

Setelah semua diposting ke dalam Buku Besar selanjutnya merekap saldo-saldo yang ada dalam Buku Besar ke dalam Neraca Saldo seperti di bawah ini : 
KOPERASI SEJAHTERAH

NERACA SALDO

s/d Bulan Desember 2020

\begin{tabular}{|l|l|r|r|r|r|}
\hline $\begin{array}{c}\text { No } \\
\text { Rek }\end{array}$ & Keterangan & \multicolumn{2}{|c|}{ Saldo 31 Des 2019 } & \multicolumn{2}{c|}{ Saldo 31 Des 2020} \\
\hline & & Debet & Kredit & \multicolumn{1}{c|}{ Debet } & \multicolumn{1}{c|}{ Kredit } \\
\hline & Kas & 2.750 .000 & & 4.491 .250 & \\
\hline & Piutang & & & 675.000 & \\
\hline & Aktiva Tetap & & & 500.000 & \\
\hline & Ak Peny AT & & & & \\
\hline & Simp Pokok & & 2.500 .000 & & 3.100 .000 \\
\hline & Simp Wajib & & 250.000 & & 2.330 .000 \\
\hline & Pendp Jasa & & & & 386.250 \\
\hline & Pendp Adm & & & & 60.000 \\
\hline & Beban Orgn & & & 150.000 & \\
\hline & Beban Adm & & & 60.000 & \\
\hline & & $\mathbf{2 . 7 5 0 . 0 0 0}$ & $\mathbf{2 . 7 5 0 . 0 0 0}$ & $\mathbf{5 . 8 7 6 . 2 5 0}$ & $\mathbf{5 . 8 7 6 . 2 5 0}$ \\
\hline
\end{tabular}

\section{Langkah 5}

Setiap akhir periode koperasi harus melakukan penyesuaian terhadap asetnya. Tujuannya adalah mengoreksi akun/perkiraan sehingga laporan yang dibuat berdasarkan akun tersebut dapat menunjukkan yang lebih sesuai. Jurnal yang dipakai adalah jurnal penyesuaian. Dari transaksi diatas 
Koperasi Sejahterah harus melakukan penyusutan terhadap asset yang dia miliki. Jurnal tersebut adalah

Beban Peny Aktiva Tetap

16.667
Ak. Peny. Aktiva Tetap
$16.667 *$

* $\underline{500.000} \times 2 / 12=16.667$

5

Jurnal Penyesuaian tersebut di posting kedalam Buku Besar dan setelah itu di buat Neraca Saldo setelah penyesuaian dan dilannjut dengan membut laporan keuangan yang berupa : Laporan Perhitungan Hasil Usaha, Laporan Perubahan Modal/Ekuitas, Neraca.

KOPERASI SEJAHTERAH

NERACA SALDO

\begin{tabular}{|l|l|r|r|r|r|r|r|}
\hline $\begin{array}{c}\text { No } \\
\text { Rek }\end{array}$ & Keterangan & \multicolumn{2}{|c|}{ Saldo 31 Des 2020 } & \multicolumn{2}{c|}{ Penyesuaian } & \multicolumn{2}{c|}{$\begin{array}{c}\text { Saldo setelah } \\
\text { disesuaikan }\end{array}$} \\
\hline & & Debet & Kredit & Debet & Kredit & Debet & Kredit \\
\hline & Kas & 4.491 .250 & & & & 4.491 .250 & \\
\hline & Piutang & 675.000 & & & & 675.000 & \\
\hline & Akt Tetap & 500.000 & & & & 500.000 & \\
\hline & Ak Peny AT & & & & 16.667 & & 16.667 \\
\hline & Simp Pokok & & 3.100 .000 & & & & 3.100 .000 \\
\hline & Simp Wajib & & 2.330 .000 & & & & 2.330 .000 \\
\hline & Pendp Jasa & & 386.250 & & & & 386.250 \\
\hline
\end{tabular}




\begin{tabular}{|c|c|c|c|c|c|}
\hline Pendp Adm & & 60.000 & & & 60.000 \\
\hline Beban Org & 150.000 & & & 150.000 & \\
\hline Beban Adm & 60.000 & & & 60.000 & \\
\hline & 5.876 .250 & 5.876 .250 & - & 5.876 .250 & 5.892 .917 \\
\hline B. Peny AT & & & 16.667 & 16.667 & \\
\hline & & & & 5.892.917 & 5.892 .917 \\
\hline
\end{tabular}

\section{LAPORAN PERHITUNGAN SISA HASIL USAHA}

\section{PER 31 DESEMBER 2020}

Pendapatan Jasa

Pendapatan

Administrasi

Total Pendapatan

Beban Organisasi

Beban Administrasi

Beban Penyusutan

Total Beban

Total SHU
386.250

60.000

\begin{tabular}{rr}
\hline $\begin{array}{c}60.000 \\
150.000\end{array}$ & 446.250 \\
60.000 & \\
16.667 & \\
\hline & \\
\hline & 226.667 \\
\hline
\end{tabular}

Laporan Perubahan Modal

Per 31 Desember 2020

Modal awal 1 Jan 2020

2.750 .000

Tambahan :

SP dan SW Anggota

Hasil Usaha tahun 2020
2.680 .000

219.583 


\section{LAPORAN NERACA}

PER 31 DESEMBER 2020

\begin{tabular}{|l|l|r|r|l|r|}
\hline $\begin{array}{c}\text { No } \\
\text { Rek }\end{array}$ & Keterangan & & $\begin{array}{c}\text { No } \\
\text { Rek }\end{array}$ & \multicolumn{1}{|c|}{ Keterangan } & \\
\hline & Aktiva & & & Hutang/Kewajiban: & - \\
\hline & Kas & 4.491 .250 & & Simp Suka Rela & - \\
\hline & Piutang & 675.000 & & Dana-dana SHU & - \\
\hline & Aktiva Tetap & 500.000 & & Tot Hut & \\
\hline & Ak Peny AT & -16.667 & & Modal/Ekuitas : & \\
\hline & & & & Simp Pokok & 3.100 .000 \\
\hline & & & & Simp Wajib & 2.330 .000 \\
\hline & & & & SHU & 219.583 \\
\hline & & & & Tot Modal & $\mathbf{5 . 6 4 9 . 5 8 3}$ \\
\hline & & & & & $\mathbf{5 . 6 4 9 . 5 8 3}$ \\
\hline & Tot Aktiva & $\mathbf{5 . 6 4 9 . 5 8 3}$ & & Tot Pasiva & \\
\hline
\end{tabular}

\section{Langkah 7}

Menutup semua akun Pendapatan dan Beban sehingga menjadi nol.

a. Menutup semua Akun Pendapatan

Pendapatan Jasa .............. 386.250

Pendapatan Administrasi ........ 60.000 
b. Menutup semua akun Beban

SHU 226.667

Beban Organisasi 150.000

Beban Transportasi ............... 60.000

Beban Penyusutan Aktiva Tetap ... 16.667

\section{Langkah 6}

Setelah diketahui berapa sisa Hasil Usaha Koperasi maka pengurus wajib melakukan perhitungan pembagian SHU. Prosentase pembagian SHU tersebut harus sesuai dengan keputusan yang telah disepakati oleh anggota pada saat RAT. Adapun prosentase SHU telah disepakati untuk Koperasi Sejahterah adalah sbb :

$20 \%$ SHU Simpanan Anggota, 20 \% SHU Pnjaman Anggota $30 \%$ Cadangan

$10 \%$ Pengurus

$10 \%$ Dana Pendidikan

$10 \%$ Dana Sosial

Dari SHU yang ada sebesar Rp 219.583 maka : 
SHU Simpanan Anggota $=219.583 \times 20 \%=43.917$

SHU Pinjaman Anggota $=219.583 \times 20 \%=43.917$

SHU Cadangan $=219.583 \times 30 \%=65.875$

SHU Pengurus, Dana Pendidikan, Dana Sosial masing-masing $=219.583 \times 10 \%=21.958$

SHU untuk masing-masing anggota :

SHU Anggota $=$ JMA + JUA

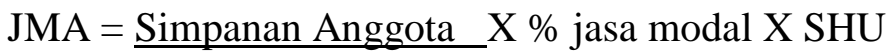

Tot simpanan koperasi

$\mathrm{JMA}=\underline{\text { Simpanan Anggota }}$ X 20\% X 219.538

5.440 .000

$=$ Simpanan Anggota X 0,80\%

$\mathrm{JUA}=$ Jasa Pinjaman Anggota X\%Jasa modal X SHU

Tot Jasa Pinjaman anggota

$=\underline{\text { Jasa Pinjaman Anggota X 20\% X } 219.538}$

386.250

$\mathrm{JUA}=$ Jasa Pinjaman Anggota X 11,37\%

Hasil dari perhitungan SHU dapat kita lihat pada table dibawah ini : 
KOPERASI MAKMUR JAYA

SHU SIMPANAN dan PINJAMAN

\begin{tabular}{|c|c|c|c|c|c|c|c|c|c|c|}
\hline \multirow{2}{*}{ NO } & \multirow{2}{*}{$\begin{array}{c}\text { NO. } \\
\text { ANGTA }\end{array}$} & \multirow{2}{*}{ NAMA } & \multirow{2}{*}{ Bln } & \multicolumn{3}{|c|}{ SIMPANAN } & \multirow{2}{*}{$\frac{\text { SHU }}{0,8 \%}$} & \multirow{2}{*}{$\begin{array}{c}\begin{array}{c}\text { Jasa } \\
\text { Pinjaman }\end{array} \\
\text { JML }\end{array}$} & \multirow{2}{*}{$\begin{array}{c}\text { SHU } \\
11,37 \%\end{array}$} & \multirow{2}{*}{$\frac{\text { TOTAL }}{\text { SHU }}$} \\
\hline & & & & РОКОК & WAJIB & JML & & & & \\
\hline 1 & & $A$ & 12 & 100.000 & 120.000 & 220.000 & 1.760 & 75.000 & 8.528 & 10.288 \\
\hline 2 & & $\mathrm{~B}$ & 12 & 100.000 & 120.000 & 220.000 & 1.760 & 75.000 & 8.528 & 10.288 \\
\hline 3 & & $C$ & 12 & 100.000 & 120.000 & 220.000 & 1.760 & 75.000 & 8.528 & 10.288 \\
\hline 4 & & $\mathrm{D}$ & 12 & 100.000 & 120.000 & 220.000 & 1.760 & 86.250 & 9.807 & 11.567 \\
\hline 5 & & $E$ & 10 & 100.000 & 100.000 & 200.000 & 1.600 & 75.000 & 8.528 & 10.128 \\
\hline 6 & & 25 Angg & 7 & 2500.000 & 1750.000 & 4250.000 & 880 & 0 & - & 880 \\
\hline \multirow[t]{2}{*}{7} & & $\mathrm{~F}$ & 1 & 100.000 & 10.000 & 110.000 & 34.000 & & & 34.000 \\
\hline & & Total & & 3.100 .000 & 2.340 .000 & 5440.000 & 43.520 & 386.250 & 43.917 & \\
\hline
\end{tabular}




\section{DAFTAR PUSTAKA}

Tuti Trisnawati. 2009. Akuntansi Untuk Koperasi dan UKM. Jakarta Salemba Empat.

Ikatan Akuntan Indonesia.2007. Standart Akuntansi Keuangan (PSAK) No 27, Akuntansi Perkoperasian (revisi 1998). Jakarta: Salemba Empat.

Rudianto.2012. Pengantar Akuntansi Konsep \& Teknik Penyusunan Laporan Keuangan Adaptasi IFRS. Jakarta: Erlangga

https://caraharian.com/cara-mencari-shu.html https://lifepal.co.id/media/cara-menghitung-shu-danpengertiannya/

Undang-undang No 25 Tahun 1992 Tentang Perkoperasian 
I8EN 078-623-6081-29-3 [FDF]

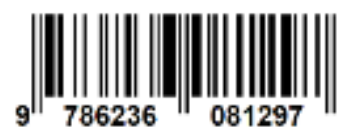

